\title{
Insulin activation of insulin receptor kinase in erythrocytes is not altered in non-insulin-dependent diabetes and not influenced by hyperglycemia
}

\author{
H H Klein, R Müller, M Drenckhan, M Schütt, B Bätge and \\ H-L Fehm \\ Department of Internal Medicine 1, Medizinische Universität zu Lübeck, Lübeck, Germany \\ (Requests for offprints should be addressed to H H Klein, Medizinische Klinik 1, Medizinische Universität zu Lübeck, Ratzeburger Allee 160, D-23538 Lübeck, \\ Germany; Email: Klein@medinf.mu-luebeck.de)
}

\begin{abstract}
Recent studies suggest that high glucose concentrations impair insulin receptor phosphorylation and kinase activation in certain cell models. To examine whether such an effect of glucose can also be demonstrated in vivo, insulin receptor kinase activation was studied in erythrocytes from 11 patients with non-insulin-dependent diabetes (NIDDM), before and after reduction of hyperglycemia (from $14.6 \pm 1.6$ to $6.6 \pm 0.5 \mathrm{mmol} / 1$ fasting plasma glucose within $8 \cdot 6 \pm 0 \cdot 6$ days). For the measurement of receptor kinase activation, cells were incubated with insulin $(0-400 \mathrm{nmol} / \mathrm{l})$, solubilized and insulin receptors immobilized to microwells coated with antiinsulin receptor antibody. Kinase activity towards insulin receptor substrate-1 and insulin binding were then measured in these wells. Kinase activities (expressed as amol phosphate transferred per min and per fmol insulin
\end{abstract}

binding activity) were similar before $(2 \cdot 4 \pm 0 \cdot 4$ and $32 \cdot 2 \pm 2 \cdot 0 \mathrm{amol} / \mathrm{min}$ per fmol with 0 and $400 \mathrm{nmol} / 1$ insulin, respectively) and after improvement of metabolic control $(2 \cdot 4 \pm 0.5$ and $32 \cdot 0 \pm 2 \cdot 3 \mathrm{amol} / \mathrm{min}$ per fmol with 0 and $400 \mathrm{nmol} / 1$ insulin, respectively). Moreover, activities were also similar in 22 hyperglycemic patients with NIDDM $(2 \cdot 1 \pm 0.3$ and $35.1 \pm 1 \cdot 4 \mathrm{amol} / \mathrm{min}$ per fmol with 0 and $400 \mathrm{nmol} / \mathrm{l}$ insulin, respectively) compared with those in 21 non-diabetic control individuals $(2 \cdot 1 \pm 0 \cdot 3$ and $34 \cdot 2 \pm 1 \cdot 2 \mathrm{amol} / \mathrm{min}$ per fmol with 0 and $400 \mathrm{nmol} / 1$ insulin, respectively). We conclude that insulin activation of erythrocyte insulin receptor kinase is not impaired in NIDDM and is not influenced by hyperglycemia.

Journal of Endocrinology (2000) 166, 275-281

\section{Introduction}

In patients with non-insulin-dependent diabetes mellitus (NIDDM), insulin resistance is a key metabolic abnormality, and genetic factors appear to be pivotal in its development (DeFronzo et al. 1992). If hyperglycemia is present, this hyperglycemia by itself contributes further to the insulin resistance. This is supported by human and animal studies that have shown that hyperglycemia can cause impaired insulin action in vitro and insulin resistance in vivo (Rosetti et al. 1990, Yki-Jarvinen 1992). The mechanisms that lead to the insulin resistance in NIDDM and the mechanisms by which hyperglycemia causes insulin resistance are not completely understood.

The hyperglycemia-induced insulin resistance appears to be mediated, at least in part, by an increased flux through the hexosamine biothynthetic pathway (Hebert et al. 1996, McClain et al. 1996) and the accumulation of metabolites of this pathway (Hawkins et al. 1997). The exact mechanisms by which insulin signaling or the function of the glucose transporter effector system are impaired are, however, not clear. Studies with cultured cells with overexpressed insulin receptors have suggested that high glucose concentrations impair insulin-stimulated insulin receptor autophosphorylation and kinase activation (Berti et al. 1994, Maegawa et al. 1995, Kroder et al. 1996, Pillay et al. 1996). Such a mechanism could contribute to hyperglycemia-induced insulin resistance in humans. Moreover, because a reversal of the glucose-induced impairment of the receptor function was observed with the thiazolidinedione troglitazone in these cells, it has been speculated that the hyperglycemia-induced impairment of receptor kinase activation could represent a target for therapeutic intervention (Kellerer et al. 1994).

In the present study, we investigated whether such hyperglycemia-induced alterations in insulin receptor function could also be demonstrated in hyperglycemic patients with NIDDM. An assay system was established that makes it possible to determine insulin-induced insulin receptor kinase activation in intact erythrocytes from only 
$2 \mathrm{ml}$ of heparinized blood. With this assay, insulin receptor kinase activation was measured in patients with NIDDM, before and after therapeutic reduction of hyperglycemia. Moreover, to investigate whether NIDDM might be associated with an impaired insulin-stimulated insulin receptor kinase activation in erythrocytes independent of the hyperglycemia, receptor kinase activation was also compared between patients with NIDDM and non-diabetic control individuals.

\section{Participants and Methods}

\section{Participants}

We recruited only those individuals who, on evaluation by clinical and standard laboratory examinations, had no renal, hepatic, infectious or endocrine diseases other than diabetes. Before the volunteers entered the study, the purpose and risks of the experimental procedure were carefully explained to them, and their informed consent was obtained. The procedure was approved by the local ethics Committees and was in accordance with the Helsinki II Declaration.

\section{Erythrocyte insulin receptor kinase and binding activities}

Between $0730 \mathrm{~h}$ and $0830 \mathrm{~h}$ after the participants had undergone an overnight fast and before they had taken any medication, $20 \mathrm{ml}$ blood were directly drawn into a vial that contained heparin (final concentration $3.5 \mathrm{U} / \mathrm{ml}$ ). Aliquots $(2 \mathrm{ml})$ of the blood were then transferred to $5 \mathrm{ml}$ polyethylene vials (Nunc, Wiesbaden, Germany) and preincubated for $5 \mathrm{~min}$ in a rotary waterbath $\left(37^{\circ} \mathrm{C}\right.$, 70 r.p.m.). Insulin (0-400 nmol/1 final concentration) was then added and incubations continued for $15 \mathrm{~min}$. The blood was then rapidly transferred to glass tubes for manual tissue grinding (Braun, Melsungen, Germany) that were filled with $1000 \mu \mathrm{l}$ ice-cold buffer (1\% Triton X-100, $2.5 \mathrm{mmol} / 1$ phenylmethylsulfonylfluoride, 800 trypsin inhibitor units $/ \mathrm{ml}$ aprotinin, $8 \mathrm{mmol} / 1 \mathrm{EDTA}, 8 \mathrm{mg} / \mathrm{ml}$ bacitracin, $2.5 \mathrm{mg} / \mathrm{ml}$ benzamidine, $2.5 \mu \mathrm{g} / \mathrm{ml}$ pepstatin, $2.5 \mu \mathrm{g} / \mathrm{ml}$ leupeptin, $160 \mathrm{mmol} / 1 \mathrm{NaF}, 10 \mathrm{mmol} / 1$ sodium pyrophosphate, $0 \cdot 2 \mathrm{mmol} / 1$ sodium vanadate, $2 \mathrm{mmol} / \mathrm{l}$ dichloroacetic acid, and $20 \mathrm{mmol} / 1$ HEPES, $\mathrm{pH} 7 \cdot 4$ ), and the cells quickly broken by the investigator manually moving the pestle up and down 30 times. Samples were kept on ice for an additional $20 \mathrm{~min}$, centrifuged for $15 \mathrm{~min}$ at $100000 \mathrm{~g}$ to remove insoluble material and stored at $-80{ }^{\circ} \mathrm{C}$. Insulin receptor kinase activity with recombinant insulin receptor substrate (IRS)-1 (Upstate Biotechnology Incorporated, New York, NY) as substrate and binding activity were then measured essentially as previously described (Klein et al. 1999). Kinase activity was expressed as amol phosphate transferred to IRS-1 per min and per fmol insulin binding activity. Briefly, samples were thawed, twice concentrated by vacuum centrifugation, and added for $16 \mathrm{~h}$ to microwells coated with monoclonal anti-insulin receptor antibody. Wells were then washed and phosphorylation reactions performed with the immobilized insulin receptors by adding a mixture containing $0.05 \%$ Triton X-100, $60 \mathrm{mmol} / 1$ $\mathrm{NaCl}, 1.5 \mathrm{mmol} / 1 \mathrm{KCl}, 0.6 \mathrm{mmol} / 1 \mathrm{CaCl}_{2}, 0.06 \mathrm{mmol} / \mathrm{l}$ sodium vanadate, $12 \mathrm{mmol} / 1 \mathrm{HEPES}, 5 \mathrm{mmol} / 1 \mathrm{MnCl}_{2}$, $10 \mathrm{mmol} / 1 \mathrm{MgCl}_{2}, 500 \mu \mathrm{mol} / 1 \mathrm{CTP}, 0 \cdot 3 \mu \mathrm{mol} / 1{ }^{32} \mathrm{P}-\mathrm{ATP}$ $(100-200 \mathrm{Ci} / \mathrm{mmol})$ and $2 \cdot 3 \mu \mathrm{g} / \mathrm{ml}$ recombinant IRS-1, $\mathrm{pH} 7 \cdot 4$, for $120 \mathrm{~min}$ at $4{ }^{\circ} \mathrm{C}$ (phoshate incorporation into IRS-1 was linear with time during this period). Reactions were stopped by adding $15 \mu \mathrm{l}$ of a solution that contained phosphatase and kinase inhibitors (final concentrations: $160 \mathrm{mmol} / \mathrm{l} \mathrm{NaF}, 10 \mathrm{mmol} / \mathrm{l}$ sodium pyrophosphate, $0.2 \mathrm{mmol} / 1$ sodium vanadate, $2 \mathrm{mmol} / 1$ dichloroacetic acid, $8 \mathrm{mmol} / 1$ EDTA and $20 \mathrm{mmol} / 1$ HEPES, $\mathrm{pH} 7 \cdot 4$ ), and the supernatant transferred to anti-phosphotyrosine antibody-coated microwells. After $16 \mathrm{~h}$ at $4{ }^{\circ} \mathrm{C}$, wells were washed and the bound IRS-1 detached by adding a solution of $2 \%$ SDS for $30 \mathrm{~min}$ (room temperature). The radioactivity in the collected SDS solution was determined by $\beta$-counting. $\left[{ }^{125} \mathrm{I}-\mathrm{Tyr}-\mathrm{A}^{14}\right]$ Monoiodoinsulin binding to immobilized insulin receptors was measured in the wells as described previously (Klein et al. 1999). Non-specific insulin binding determined in the presence of $3.5 \mu \mathrm{mol} / 1$ unlabeled insulin was $<0.5 \%$. Insulin binding activity was defined as the amount of specifically bound insulin at a concentration of $8.7 \mathrm{nmol} / \mathrm{l}$ (Klein et al. 1995). Experiments with leukocyte filters (RC 50 KCE, Pall-Newquay, Cornwall, UK) showed that almost complete removal of the leukocytes from the blood did not alter measured binding or kinase activities expressed per erythrocyte, indicating that the contribution of the leukocytes to the measured kinase and binding activities was negligible (data not shown). Although the measurements were performed in whole blood, the results therefore reflect, almost exclusively, erythrocyte receptor binding and kinase activities.

\section{Results}

\section{Reduction of plasma glucose and erythrocyte insulin receptor kinase activity}

The effect of a therapeutic reduction in hyperglycemia was studied in 11 patients (four women, seven men) with NIDDM (ages $59 \pm 4$ years, body mass index (BMI) $27 \cdot 7 \pm 1 \cdot 7 \mathrm{~kg} / \mathrm{m}^{2}$, glycated hemoglobin (HbA1c) $13 \cdot 2 \pm 0 \cdot 3 \%$ ). As shown in Fig. 1, mean daily preprandial plasma glucose concentrations (measured at $1100 \mathrm{~h}$, $1700 \mathrm{~h}$ and $0700 \mathrm{~h}$ ) were decreased from $17 \cdot 6 \pm 1$ to $6.6 \pm 0.4 \mathrm{mmol} / 1(P<0.001$, paired $t$-test $)$ in $8.6 \pm 0.6$ days. Plasma insulin concentrations were $122 \pm 34$ and $91 \pm 17 \mathrm{mU} / \mathrm{ml}$ (not significant; data not shown) when blood was drawn for first and second insulin receptor 


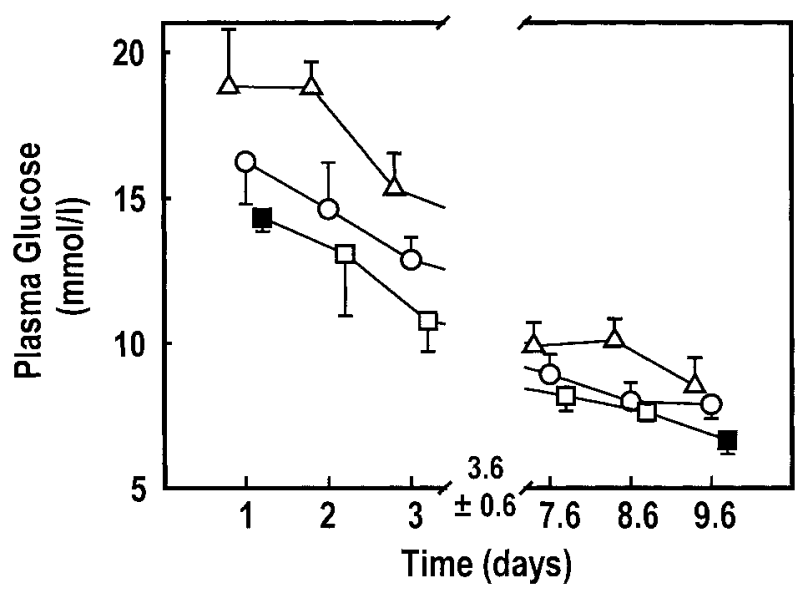

Figure 1 Effects of the therapeutic intervention on plasma glucose concentrations. Eleven patients with NIDDM and hyperglycemia were admitted to hospital. On the first morning after admission (day 1), blood for receptor kinase measurements was drawn as described in Methods. Hyperglycemia was treated with diet alone $(n=1)$, initiation of sulfonylurea $(n=2)$, initiation of insulin therapy $(n=5)$, or adaptation of previous insulin treatment $(n=3)$. Blood for receptor kinase measurements was obtained again after $8.6 \pm 0.6$ days. Preprandial plasma glucose concentrations are shown for $1100 \mathrm{~h}(\triangle), 1700 \mathrm{~h}(\bigcirc)$ and $0700 \mathrm{~h}(\square, \boldsymbol{\square})$ on the first 3 days after admission and on the 3 days before the second kinase measurement. Data represent means \pm S.E. $\boldsymbol{\square}$, Time points when blood was drawn for the measurements of receptor kinase and insulin binding activities.

kinase activity measurements, respectively. The reduction in plasma glucose concentrations was not associated with an alteration of the insulin binding activity that was extracted from the erythrocytes (Fig. 2A) or an altered efficiency of $400 \mathrm{nmol} / 1$ insulin to stimulate erythrocyte insulin receptor kinase activity (Fig. 2B). A maximal

Figure 2 Effects of the therapeutic intervention on insulin binding and insulin receptor kinase activities in erythrocytes. Aliquots of the blood samples obtained from the 11 patients before $(\square)$ or after (hatched bars) reduction of plasma glucose concentrations were incubated for $15 \mathrm{~min}$ with 0 or $100 \mathrm{nmol} / \mathrm{l}$ insulin $(\mathrm{A}, \mathrm{B})$ or with increasing insulin concentrations $(C)$ as described in Methods. The cells were then solubilized, insulin receptors immunoimmobilized to anti-insulin receptor antibody-coated microwells, and insulin receptor kinase and binding activities measured. (A) Insulin binding activity: amount of insulin that bound to immobilized insulin receptors from $2 \times 10^{8}$ erythrocytes in the presence of $8.7 \mathrm{nmol} / \mathrm{l}$ insulin. Data represent means \pm S.E. (bars) or individual data (circles); lines connect values obtained in the same individual before and after reduction in plasma glucose. (B) Insulin receptor kinase activity: insulin receptor-mediated incorporation of phosphate $(\mathrm{P})$ into recombinant IRS-1 per min and per fmol insulin binding activity of the receptors. Presentation of data as in (A). (C) Concentration-response curves for insulin activation of receptor kinase: effect of the indicated insulin concentrations on insulin receptor kinase activity, expressed as percentage of the maximal insulin effect ( $400 \mathrm{nmol} / \mathrm{l}$ insulin). Concentration-response curves were measured only in eight of the 11 patients; data represent means \pm S.E. stimulation of the insulin receptor kinase in erythrocytes was produced by $400 \mathrm{nmol} / 1$ insulin (data not shown). To explore whether differences in insulin receptor kinase activation before and after the reduction in glucose concentrations might have existed at submaximal insulin concentrations, concentration-response curves were measured in eight of the 11 patients (Fig. 2C). Similar concentration-response curves were obtained, indicating that plasma glucose concentrations also had no effect on receptor kinase activation at submaximal insulin concentrations.
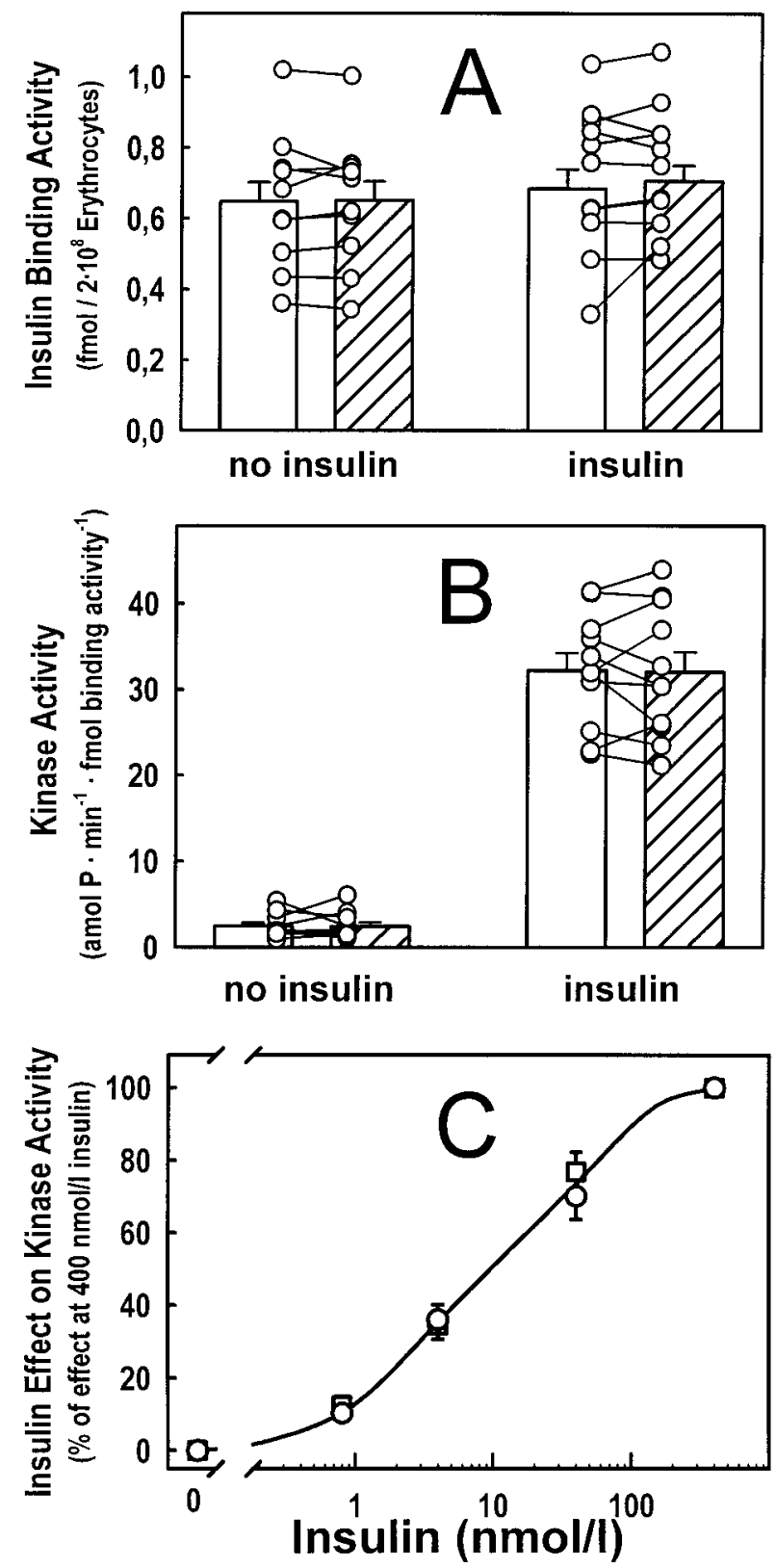

Journal of Endocrinology (2000) 166, 275-281 


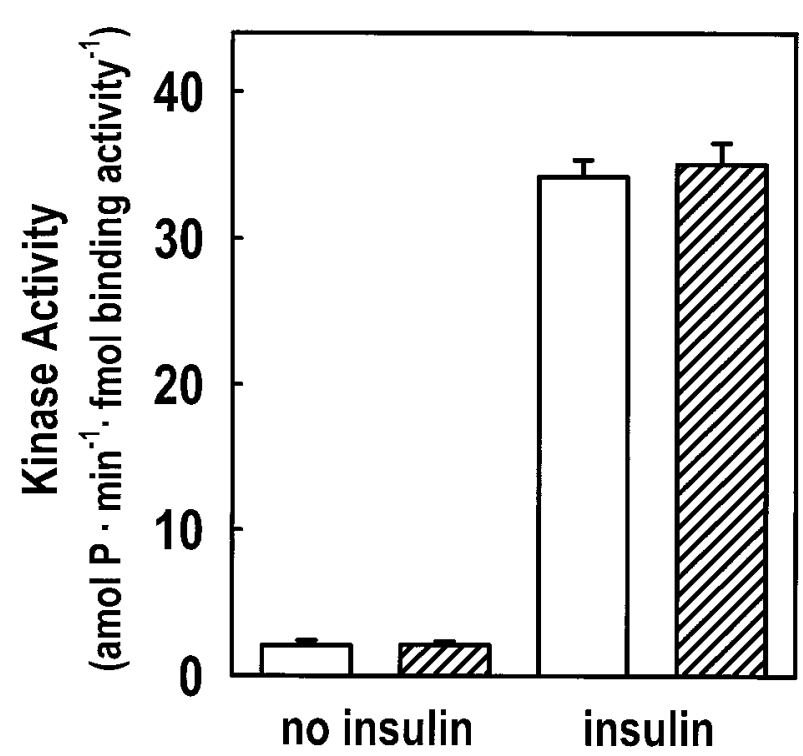

Figure 3 Activation of insulin receptor kinase in erythrocytes from patients with (hatched bars) or without $(\square)$ NIDDM. Blood from 22 individuals with NIDDM and 21 non-diabetic control individuals was incubated in the presence or absence of $400 \mathrm{nmol} / \mathrm{l}$ insulin. Insulin receptor kinase activity was then measured as described. Means \pm S.E.

Insulin activation of insulin receptor kinase in erythrocytes from individuals with and without NIDDM

Insulin activation of insulin receptor kinase was also compared in 22 patients (12 women, 10 men) with NIDDM (ages $64 \pm 3$ years, BMI $27 \cdot 9 \pm 1 \mathrm{~kg} / \mathrm{m}^{2}$, $\mathrm{HbA} 1 \mathrm{c} \quad 9 \cdot 8 \pm 0 \cdot 6 \%$, fasting plasma glucose (FPG) $9 \cdot 8 \pm 0.6 \mathrm{mmol} / \mathrm{l}$, fasting serum insulin $84 \pm 9 \mathrm{pmol} / \mathrm{l})$ and 21 non-diabetic control individuals (nine women, 12 men; ages $63 \pm 3$ years, BMI $27 \cdot 5 \pm 1 \mathrm{~kg} / \mathrm{m}^{2}, \mathrm{HbA} 1 \mathrm{c}$ $6 \cdot 3 \pm 0 \cdot 1 \%$, FPG $4 \cdot 6 \pm 0 \cdot 1 \mathrm{mmol} / \mathrm{l}$, fasting serum insulin $43 \pm 4 \mathrm{pmol} / \mathrm{l})$. No differences were found between the two groups (Fig. 3). The insulin binding activity that was extracted from the erythrocytes was also not different (volunteers without diabetes: $0.79 \pm 0.06$ and $0.84 \pm 0.07 \mathrm{fmol}$ insulin binding activity per $2 \times 10^{8}$ erythrocytes in erythrocytes stimulated with 0 or $400 \mathrm{nmol} / 1$ insulin respectively; patients with diabetes: $0.77 \pm 0.05$ and $0.82 \pm 0.06 \mathrm{fmol}$ insulin binding activity per $2 \times 10^{8}$ erythrocytes in erythrocytes stimulated with 0 or $400 \mathrm{nmol} / 1$ insulin respectively).

\section{Discussion}

The molecular mechanism for hyperglycemia-induced insulin resistance is unclear. Findings in cultured cells with overexpressed insulin receptors (rat embryo fibroblasts (Berti et al. 1994, Kellerer et al. 1994, Maegawa et al. 1995, Pillay et al. 1996) or NIH3T3-cells (Kroder et al.
1996)) have suggested that an impaired insulin-stimulated insulin receptor kinase activation may cause or contribute to the effect of glucose on insulin sensitivity. In tissues of hyperglycemic patients with NIDDM such a mechanism could cause or worsen insulin resistance, and it has been suggested that the hyperglycemia-induced impairment of receptor kinase activation could be a target for therapeutic intervention (Kellerer et al. 1994). The initial goal of the present study was therefore to establish a simple assay that allows evaluation of such secondary alterations in insulininduced receptor kinase activation in patients. With the technique described in the present report, only $20 \mathrm{ml}$ of blood is required to obtain a complete concentrationresponse curve, and this is particularly advantageous if multiple measurements at different time points are required. Insulin activation of the receptor kinase occurs in situ in the intact erythrocytes which, compared with most previous studies in which receptors were insulinstimulated in a cell-free system (Comi et al. 1987, Santos et al. 1994, Sowers et al. 1995), represents a more physiological situation. Moreover, this in situ stimulation can be performed in the complete heparinized blood, without the need of prior erythrocyte isolation. It is therefore likely that in vivo conditions are better maintained than, for example, in adipocytes, in which the isolation procedure takes approximately $1 \mathrm{~h}$. Finally, compared with previous studies by our own group (Klein et al. 1995, 1997), we now used recombinant IRS-1 as a physiologic substrate, instead of a synthetic polymer.

Were an effect of glucose on insulin-stimulated receptor kinase activation such as is described in cultured cells with overexpressed insulin receptors (Berti et al. 1994, Kellerer et al. 1994, Maegawa et al. 1995, Kroder et al. 1996, Pillay et al. 1996) also to exist in erythrocytes of hyperglycemic patients with NIDDM, a reduction in pathologically increased plasma glucose concentrations should result in a reversal of this effect. Therapeutic reduction of hyperglycemia in patients with NIDDM did not, however, result in a detectable alteration in the effect of insulin on insulin receptor kinase activation in their erythrocytes. Moreover, erythrocyte insulin receptor kinase activation was not different between hyperglycemic patients with NIDDM and euglycemic non-diabetic control individuals. These data suggest that the effects of glucose on receptor kinase activation observed in cultured cell models may not be present under 'in vivo' conditions, at least not in the presence of mean preprandial serum glucose concentrations less than $18 \mathrm{mmol} / 1$ and/or not in all tissues.

A potential explanation for the observation of an effect of glucose in cultured cell systems, but not in our study, could be that glucose concentrations ( 25 or $27 \mathrm{mmol} / \mathrm{l}$ ) used in the studies with the cultured cells (Berti et al. 1994, Kellerer et al. 1994, Maegawa et al. 1995, Kroder et al. 1996, Pillay et al. 1996) were greater than the initial mean daily preprandial serum glucose concentrations in the hyperglycemic patients in our study 
$(17 \cdot 6 \pm 1 \cdot 0 \mathrm{mmol} / \mathrm{l})$. Only in one of these studies (Pillay et al. 1996) were measurements also performed in the presence of lower glucose concentrations, and no effects of glucose on receptor kinase activation were apparent with concentrations of $20 \mathrm{mmol} / 1$ or less. To explore the possibility that greater glucose concentrations than those reached in our in vivo study might affect insulin receptor kinase activation in erythrocytes, we incubated heparinized blood in vitro for $3 \mathrm{~h}$ at $37^{\circ} \mathrm{C}$ with 27 or $4 \mathrm{mmol} / 1$ glucose. No glucose-induced impairment of insulin-stimulated receptor kinase was observed (data not shown), suggesting either that the exposure to glucose was too short, or that insulin receptor kinase activity, in contrast to the cultured cell systems mentioned above, is not responsive to glucose.

There are several lines of evidence that the effects of glucose on the insulin receptors described in the cultured cell systems are mediated, at least in part, by protein kinase $\mathrm{C}$ (PKC). High glucose concentrations have been shown to lead to PKC activation (Lee et al. 1989) and the translocation of certain PKC isoforms (e.g. PKCa (Berti et al. 1994)), potentially by mechanisms related (Filippis et al. 1997) or not related (Laybutt et al. 1999) to an increased flux through the hexosamine biothynthetic pathway. This PKC activation and/or translocation may result in an increased serine phosphorylation of the insulin receptor and/or IRS-1 which, in turn, has been linked to impaired receptor kinase activation and downstream signaling (Bollag et al. 1986, Takayama et al. 1988, Hotamisligil et al. 1996). Erythrocytes contain PKC that can be stimulated by phorbol-myristate 13 -acetate, and it has also been shown that the PKC $\alpha$ isoform can be activated and translocated to the plasma membrane in erythrocytes (Fathallah et al. 1997). Another proposed mechanism for the glucose-mediated reduction in insulin receptor kinase activation in rat embryo fibroblasts with overexpressed insulin receptors involves alterations in phosphotyrosine phosphatase activity (Maegawa et al. 1995). Phosphotyrosine phosphatase-1B (PTP-1B) appears to have a major role in the dephosphorylation of the insulin receptor and IRS-1 (Goldstein et al. 2000), and erythrocytes contain a phosphotyrosine phosphatase that immunoprecipitates with monoclonal antibodies against this phosphatase (Zipser \& Kosower 1996), and therefore most probably represents PTP-1B. It is nevertheless possible that erythrocytes lack certain components that are present in the cultured cell systems and that are necessary for the effect of glucose on receptor kinase activity or its reversal.

As the cultured rat embryo fibroblasts or NIH3T3-cells with overexpressed receptors (Berti et al. 1994, Kellerer et al. 1994, Maegawa et al. 1995, Kroder et al. 1996, Pillay et al. 1996) also do not represent typical insulin target tissues, it can also be questioned whether such components are operative in more relevant tissues such as adipocytes, liver or skeletal muscle. In fact, no effects of glucose on insulin-induced in situ insulin receptor autophosphorylation or receptor kinase activity were observed in cultured rat adipocytes (Lima et al. 1991). Likewise, no improvement of the effect of insulin on receptor autophosphorylation was observed in liver insulin receptors from hyperglycemic rats when hyperglycemia was reduced from 27 to $6 \mathrm{mmol} / \mathrm{l}$ by phlorizin treatment (Considine et al. 1995), and in a recent study a hyperglycemiainduced reduction of protein kinase $\mathrm{B}$ (PKB) but not phosphatidylinositol 3-kinase, activity was observed in rat skeletal muscle - suggesting that the preceding steps of insulin signaling such as receptor kinase activation were not altered (Kurowski et al. 1999). In contrast to the findings of that study, Kim et al. (1999) and Patti et al. (1999) found normal PKB activation and reduced phosphatidylinositol $3^{\prime}$-kinase activation in rat skeletal muscle when they stimulated the hexosamine pathway with glucosamine instead of glucose. With respect to our data it is, however, important to note that insulin-stimulated insulin receptor phosphorylation was not affected in either of the above studies, despite the glucosamine-induced reduction in insulin-stimulated phosphatidylinositol $3^{\prime}$ kinase activity. Our finding that hyperglycemia did not affect insulin-stimulated insulin receptor kinase activation in human erythrocytes is therefore consistent with previous studies in more relevant target tissues in animals.

Our present observation that insulin receptor kinase activation is not impaired in erythrocytes from patients with NIDDM compared with those from non-diabetic control individuals is in contrast to the findings of studies in which reduced insulin receptor autophosphorylation and/or kinase activity was measured after insulin stimulation of erythrocyte receptors in a cell-free system (Comi et al. 1987, Santos et al. 1994). It is, however, consistent with data reported by Hagino et al. (1994) who, similarly to our study procedure, stimulated the intact erythrocytes with insulin, and found no difference in receptor autophosphorylation between patients with NIDDM and non-diabetic controls. Our finding that in situ insulin activation of receptor kinase was not different in erythrocytes from those with and without NIDDM is also consistent with data on human skeletal muscle obtained by our group (Klein et al. 1995) and others (Krook et al. 1999).

In summary, our data indicate that mean daily preprandial glucose concentrations of approximately $18 \mathrm{mmol} / 1$ do not impair insulin receptor kinase activation in erythrocytes from patients with NIDDM. The assay described can therefore not be used to monitor hyperglycemia-induced changes in insulin signaling and insulin sensitivity in patients. Moreover, our data in the human erythrocyte model confirm the findings of other studies in animal models that suggest that the hyperglycemia-induced insulin resistance appears to be mainly caused by mechanisms affecting insulin signaling steps downstream of the insulin receptor kinase. To our 
knowledge, no similar study in patients has so far been performed with other, more relevant tissues.

\section{Acknowledgements}

This work was supported by grants from the Deutsche Forschungsgemeinschaft (K1503/7-3) and the EC (BMH4-CT960751). This work contains major parts of the thesis of $\mathrm{R} M$.

\section{References}

Berti L, Mosthaf L, Kroder G, Kellerer M, Tippmer S, Mushack J, Seffer E, Seedorf K \& Haring H 1994 Glucose-induced translocation of protein kinase $\mathrm{C}$ isoforms in rat-1 fibroblasts is paralleled by inhibition of the insulin receptor tyrosine kinase. Journal of Biological Chemistry 269 3381-3386.

Bollag GE, Roth RA, Beaudoin J, Mochly-Rosen D \& Koshland DE Jr 1986 Protein kinase C directly phosphorylates the insulin receptor in vitro and reduces its protein-tyrosine kinase activity. PNAS 83 5822-5824.

Comi RJ, Grunberger G \& Gorden P 1987 Relationship of insulin binding and insulin-stimulated tyrosine kinase activity is altered in type II diabetes. Journal of Clinical Investigation 79 453-462.

Considine RV, Nyce MR, Allen LE, Morales LM, Triester S, Serrano J, Colberg J, Lanza-Jacoby S \& Caro JF 1995 Protein kinase C is increased in the liver of humans and rats with non-insulindependent diabetes mellitus: an alteration not due to hyperglycemia. Journal of Clinical Investigation 95 938-2944.

DeFronzo RA, Bonadonna RC \& Ferrannini E 1992 Pathogenesis of NIDDM. A balanced overview. Diabetes Care 15 318-368.

Fathallah H, Sauvage M, Romero JR, Canessa M \& Giraud F 1997 Effects of PKC alpha activation on $\mathrm{Ca}^{2+}$ pump and $\mathrm{K}(\mathrm{Ca})$ channel in deoxygenated sickle cells. American Journal of Physiology 273 C1206-C1214.

Filippis A, Clark S \& Proietto J 1997 Increased flux through the hexosamine biosynthesis pathway inhibits glucose transport acutely by activation of protein kinase C. Biochemical Journal 324 981-985.

Goldstein BJ, Bittner-Kowalczyk A, White MF \& Harbeck M 2000 Tyrosine dephosphorylation and deactivation of insulin receptor substrate- 1 by protein-tyrosine phosphatase 1B. Possible facilitation by the formation of a ternary complex with the grb2 adaptor protein. Journal of Biological Chemistry 275 4283-4289.

Hagino H, Shii K, Yokono K, Matsuba H, Yoshida M, Hosomi Y, Okada Y, Kishimoto M, Hozumi T \& Ishida Y 1994 Enzymelinked immunosorbent assay method for human autophosphorylated insulin receptor. Applicability to insulin-resistant states. Diabetes 43 274-280.

Hawkins M, Angelov I, Liu R, Barzilai N \& Rosetti L 1997 The tissue concentration of UDP-N-acetylglucosamine modulates the stimulatory effect of insulin on skeletal muscle glucose uptake. Journal of Biological Chemistry 272 4889-4895.

Hebert LF, Daniels MC, Zhou J, Crook ED, Turner RK, Simmons ST, Neidigh JL, Zhu J, Baron A \& McClain DA 1996 Overexpression of glutamine:fructose-6-phosphate amidotransferase in transgenic mice leads to insulin resistance. Journal of Clinical Investigation 98 930-936.

Hotamisligil GS, Peraldi P, Budavari A, Ellis R, White MF \& Spiegelman BM 1996 IRS-1-mediated inhibition of insulin receptor tyrosine kinase activity in TNF-alpha- and obesity-induced insulin resistance. Science 271 665-668.
Kellerer M, Kroder G, Tippmer S, Berti L, Kiehn R, Mosthaf L \& Haring H 1994 Troglitazone prevents glucose-induced insulin resistance of insulin receptor in rat-1 fibroblasts. Diabetes $\mathbf{4 3}$ 447-453.

Kim YB, Zhu J-S, Zierath JR, Shen H-Q, Baron AD \& Kahn BB 1999 Glucosamine infusion in rats rapidly impairs insulin stimulation of phosphoinositide 3-kinase but does not alter activation of Akt/protein kinase B in skeletal muscle. Diabetes 48 310-320.

Klein HH, Vestergaard H, Kotzke G \& Pedersen O 1995 Elevation of serum insulin concentration during euglycemic hyperinsulinemic clamp studies leads to similar activation of insulin receptor kinase in skeletal muscle of subjects with and without NIDDM. Diabetes 44 1310-1317.

Klein HH, Kowalewski B, Drenckhan M \& Fehm HL 1997 Insulin stimulation of human adipocytes activates the kinase of only a fraction of the insulin receptors. American Journal of Physiology 272 E576-E583.

Klein HH, Muller R, Vestergaard H \& Pedersen O 1999 Implications of compound heterozygous insulin receptor mutations in congenital muscle fibre type disproportion myopathy for the receptor kinase activation. Diabetologia 42 245-249.

Kroder G, Bossenmaier B, Kellerer M, Capp E, Stoyanov B, Muhlhofer A, Berti L, Horikoshi H, Ullrich A \& Haring H 1996 Tumor necrosis factor-alpha- and hyperglycemia-induced insulin resistance. Evidence for different mechanisms and different effects on insulin signaling. Journal of Clinical Investigation 97 1471-1477.

Krook A, Bjornholm M, Jiang XJ, Galuska D, Fahlmann R, Myers MG, Wallberg-Henriksson H \& Zierath JR 2000 Characterization of signal transduction and glucose transport in skeletal muscle from type 2 diabetic patients. Diabetes 49 284-292.

Kurowski TG, Lin Y, Luo Z, Tsichlis PN, Buse MG, Heydrick SJ \& Ruderman NB 1999 Hyperglycemia inhibits insulin activation of Akt/protein kinase B but not phosphatidylinositol 3-kinase in rat skeletal muscle. Diabetes 48 658-663.

Laybutt DR, Schmutz-Pfeifer C, Saha AK, Ruderman NB, Biden TJ \& Kraegen EW 1999 Muscle lipid accumulation and protein kinase $\mathrm{C}$ activation in the insulin-resistant chronically glucose-infused rat. American Journal of Physiology 277 E1070-E1076.

Lee TS, Saltman KA, Ohashi H \& King GL 1989 Activation of protein kinase C by glucose. PNAS 86 5141-5145.

Lima FB, Thies RS \& Garvey WT 1991 Glucose and insulin regulate insulin sensitivity in primary cultured adipocytes without affecting insulin receptor kinase activity. Endocrinology 128 2415-2426.

McClain DA \& Crook ED 1996 Hexosamines and insulin resistance. Diabetes 45 1003-1009.

Maegawa H, Ide R, Hasegawa M, Ugi S, Egawa K, Iwanishi M, Kikkawa R, Shigeta Y \& Kashiwagi A 1995 Thiazolidine derivatives ameliorate high glucose-induced insulin resistance via the normalization of protein-tyrosine phosphatase activities. Journal of Biological Chemistry 270 7724-7730.

Patti ME, Virkamaki A, Landaker EJ, Kahn CR \& Yki-Jarvinen H 1999 Activation of the hexosamine pathway by glucosamine in vivo induces insulin resistance of early postreceptor insulin signaling events in skeletal muscle. Diabetes 48 1562-1571.

Pillay TS, Xiao S \& Olefsky JM 1996 Glucose-induced phosphorylation of the insulin receptor. Functional effects and characterization of phosphorylation sites. Journal of Clinical Investigation 97 613-620.

Rosetti L, Giaccari A \& DeFronzo RA 1990 Glucose toxicity. Diabetes Care 13 610-630.

Santos RF, Palmieri MG, Wajchenberg BL \& Azhar S 1994 Insulin-receptor tyrosine kinase activity is decreased in erythrocytes from non-obese patients with NIDDM. Hormone and Metabolic Research 26 283-287. 
Sowers JR, Jacobs DB, Simpson L, al-Homsi B, Grunberger G \& Sokol R 1995 Erythrocyte insulin and insulin-like growth factor-I receptor tyrosine kinase activity in hypertension in pregnancy. Metabolism 44 1308-1313.

Takayama S, White MF \& Kahn CR 1988 Phorbol ester-induced serine phosphorylation of the insulin receptor decreases its tyrosine kinase activity. Journal of Biological Chemistry 263 3440-3447.

Yki-Jarvinen H 1992 Glucose toxicity. Endocrine Reviews 13 415-431.
Zipser Y \& Kosower NS 1996 Phosphotyrosine phosphatase associated with band 3-protein in the human erythrocyte membrane. Biochemical Journal 314 881-887.

Received 11 November 1999

Revised manuscript received 21 March 2000 Accepted 11 April 2000 